\title{
Red Ear Fungi (Auricularia Auricula) Infusion Reduces Blood Triglyceride Level in Dyslipidemic Rats
}

\author{
Nareswara Anugrah Widi, ${ }^{1}$ Truly D. Sitorus, ${ }^{2}$ Coriejati Rita ${ }^{3}$ \\ ${ }^{1}$ Faculty of Medicine Universitas Padjadjaran, ${ }^{2}$ Department of Pharmacology and Therapy, \\ Faculty of Medicine Universitas Padjadjaran, ${ }^{3}$ Department of Clinical Pathology Faculty of \\ Medicine Universitas Padjadjaran/Dr. Hasan Sadikin General Hospital Bandung
}

\begin{abstract}
Background: Dyslipidemia is a risk factor in atherosclerosis. In the long run, it can cause complications such as coronary artery disease and stroke. Dyslipidemia can be halted by beta glucan, a soluble fiber found in some species of fungi. This study was conducted to find the effect of red ear fungi infusion in reducing blood triglyceride level and the concentration that would give optimal reduction of blood triglyceride level.

Methods: This analytical study used experimental laboratory methods on 25 male Wistar rats which were randomly divided into 5 groups. Group 1 received normal food and water, while group 2 was given high lipid diet (HLD) and propiltiouracil (PTU) $0.01 \%$ as drinking water. Group 3, group 4, and group 5 were given the same food as group 2, with the additional red ear fungi infusion $18 \%, 36 \%$, and $72 \%$ concentration respectively, for 14 days. Blood cholesterol level was measured on thelast day of the experiment. The group means were compared using one-way ANOVA (Analysis of Variance) and Scheffe Test as the post-hoc test. Statistical differences were considered significant at $\mathrm{p}<0.05$.

Results: The result showed that themean difference of blood triglyceride level in all three treatment groups, i.e. group 3, group 4, and group 5 (87.08, 90.40, and $82.70 \mathrm{mg} / \mathrm{dl}$ respectively) was statistically significant compared to the positive control group (172.92 mg/dl). Out of the three groups, group 4 with $36 \%$ infusion concentration had the lowest mean difference from all of the treatment groups.

Conclusions: Red ear fungi infusion reduced blood triglyceride level, and infusion with 36\% concentration was the optimal concentration in reducing blood triglyceride level. A further study can be conducted to find theconcentration rangeinwhich theinfusionreducesblood triglycerideleveloptimally. [AMJ.2015;2(1):143-6]
\end{abstract}

Keywords: Beta glucan, red ear fungi infusion, triglyceride

\section{Introduction}

In this era of globalization, increasing work load and daily routines hold a significant effect to lifestyle changes, especially in urban areas. People have the tendency to ignore healthy lifestyle by consuming fast food and doing less exercise which are both risk factors for dyslipidemia. Dyslipidemia is a condition of abnormal lipid level in blood, which can either be increased or decreased.

Currently, the mostly found condition is the increase of lipid called hyperlipidemia. Hyperlipidemia is the increase of one or more lipid components in blood plasma, such as cholesterol, triglyceride, low density lipoprotein (LDL), and the decrease of high density lipoprotein (HDL). The increase of lipid level in plasma causes endothelial wall damage, which then can become atherosclerosis, which in the long run, will cause many other diseases such as coronary artery disease and stroke. ${ }^{1}$ From data of the World Health Organization (WHO) in 2002, coronary artery disease is the first cause of death in people aged60 years and older, followed by stroke in the second place. ${ }^{2}$

Red ear fungi (Auricularia auricula) are one of the fungi used in traditional medicine, especially by people of Chinese-descent. These fungi can grow in any place, ranging from beaches to mountains. These fungi were believed to have effect in reducing blood sugar, alleviating sore throat, and reducing cholesterol level in blood. They are usually dispended by boiling $60 \mathrm{~g}$ of fungi with palm sugar as much as needed with 5 glass of water. All ingredients were boiled until the water

Correspondence: Nareswara Anugrah Widi, Faculty of Medicine, Universitas Padjadjaran, Jalan Raya BandungSumedang Km.21, Jatinangor, Sumedang, Indonesia, Phone: +62 85710126671 Email: nares.anugrah@gmail.com 
evaporated enough to leave the amount for one glass. The resulting concoction would then be consumed once a day. ${ }^{3}$

In a study conducted in South Korea, biopolymer extractions of red ear fungi were found to have triglyceride lowering effects. The triglyceride lowering effects were caused by a soluble fiber called beta glucan by inhibiting micelles production in the process of triglyceride absorption in small intestine. ${ }^{4-7}$

Based on the explanation above, the author was interested to know the effect of red ear fungi in lowering triglyceride, as one of the risk factors in atherosclerosis. Infusion was chosen because the usage of red ear fungi in society was using a method resembling infusion, besides the process of making infusion is more practicable in everyday society

\section{Methods}

This analytical study used experimental laboratory methods during the period of September to October 2012 in the Pharmacological Laboratory of Dr. Hasan Sadikin General Hospital, Bandung.

The red ear fungi were obtained from the fungi cultivation of the Indonesian Institute of Sciences or Lembaga Ilmu Pengetahuan Indonesia (LIPI) in Bogor, West Java. First of all the fungi were dried before it was used in the study. The infusion was made by cutting the dried fungi into small pieces and put in a pot. Next, water was added accordingly to the concentration made. The pot was then put into a bigger infusion pot with boiled water around $90^{\circ}$ Celsius. The fungi was then boiled in the pot and stirred constantly for 15 minutes. Afterward, it was let to cool under room temperature and then filtered using filtration paper to get a red ear fungi infusion. ${ }^{8}$

Male Wistar rats (200-300 g) were used in the study. At the first week, all 25 rats underwent adaptation with a daily normal diet and water. The rats were then divided into 5 groups using random sampling method and given different treatment. Group 1 was given normal food and water, group 2 was given high lipid diet (HLD) as food and propiltiouracil (PTU) $0.01 \%$ as drinking water without red ear fungi infusion. Group 3, group 4, and group 5 were given the same treatment as group 2, with the addition of red ear fungi infusion of $18 \%, 36 \%$, and $72 \%$ concentration respectively. A schematic diagram depicting this can be seen in Figure 1 .

At the end of the 2 weeks experiment,

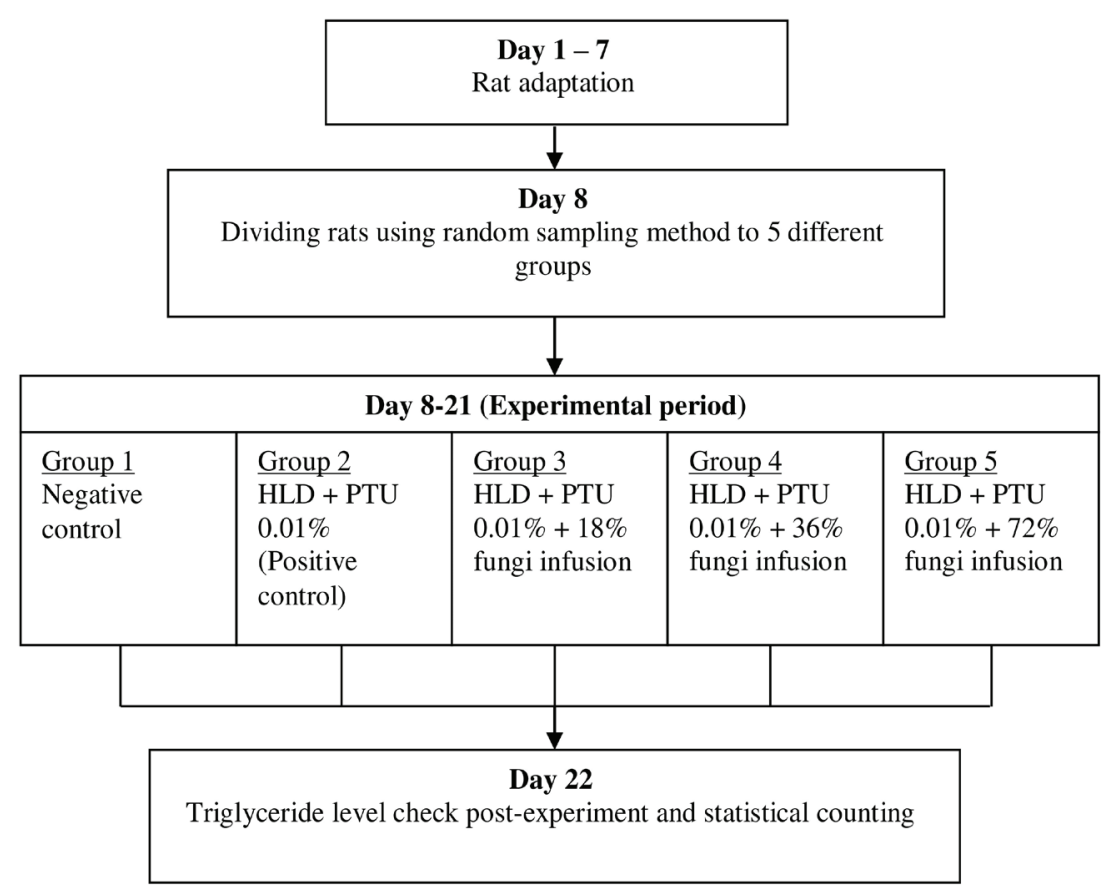

Figure 1 Experimental Diagram 
Table 1 Post-study Triglyceride Level

\begin{tabular}{cccccc}
\hline \multirow{2}{*}{ Rat number } & \multicolumn{5}{c}{ Blood Triglyceride Level (mg/dL) } \\
\cline { 2 - 6 } & Group 1 & Group 2 & Group 3 & Group 4 & Group 5 \\
\hline 1 & 62.5 & 177.3 & 76.8 & 77.1 & 104.5 \\
2 & 73.2 & 155.6 & 119.2 & 78.3 & 95.9 \\
3 & 62.1 & 193.6 & 86.4 & 100.6 & 108.1 \\
4 & 94.7 & 135.5 & 96.9 & 76.9 & 60.8 \\
5 & 79.6 & 202.6 & 49.4 & 79.7 & 81.8 \\
Mean & 74.42 & 172.92 & 85.74 & 82.52 & 90.22 \\
\hline Note: Group 1: Negative control, Group 2: Positive control, Group 3: Test group 1 (18\% infusion), Group 4: Test group 2 \\
(36\% infusion), Group 5: Test group 3 (72\% infusion)
\end{tabular}

blood was taken from the tail. The blood plasma triglyceride level was determined enzymatically using a colorimetric enzymatic test with GPO (glycerol-3-phosphate oxidase) afterwhich the resulted solution wasthen measured using a spectrophotometer with $546 \mathrm{~nm}$ wave length. ${ }^{9}$

Data distribution was analyzed using Shapiro-Wilk and data homogenity of variance were analyzed using Levene's Test. The means were compared using the one-way ANOVA (analysis of variance) and Scheffe Test as the post-hoc test. ${ }^{10,11}$ Statistical differences were considered significant at $\mathrm{p}<0.05$.

\section{Results}

To evaluate the effect of infusion of red ear fungi to blood triglyceride level, 14 days post treatment, measurement of blood triglyceride level was done. The result of the study can be seen in Table 1.

The results showed infusion of red ear fungi (group 3, 4, and 5) indicated similar level of blood triglyceride $(87.08,90.40$, and $82.70 \mathrm{mg} /$ dl respectively) was close to negative control (74.42 mg/dl) group. Statistical analysis was conducted to recognize the significance of the findings in the study. The statistical analysis can be seen in Table 2.
After the test, it was identified that all groups had the same value of significance of $0.00(\mathrm{p}<0.05)$ when compared with group 2 .

\section{Discussion}

This study was conducted using male Wistar rats induced with HLD and PTU $0.01 \%$. The HLD increased the rat lipid intake, thus increasing the triglyceride level in the blood. The PTU $0.01 \%$ was given to the water drank by the rats to block the synthesis of thyroxine hormone to down regulate lipid metabolism, increasing the triglyceride level in rats.

The successful induction of rats could be seen by comparing group 1 (negative control) and group 2 (positive control). The mean of triglyceride level in group $2(172.92 \mathrm{mg} / \mathrm{dL})$ was higher than in group 1 (74.42 mg/dL).

The effect of red ear fungi infusion could be seen by comparing the treatment group of group 3 (18\% infusion), group 4 (36\% infusion), and group 5 (72\% infusion) with group 2 (positive control). The mean of the treatment group was lower than the positive control group, showing an effect of triglyceride lowering from red ear fungi infusion. To know the significance of these findings, a statistical analysis was performed. Statistical analysis

Table 2 Post-hoc Scheffe Test Result

\begin{tabular}{ccc}
\hline Group & Mean Difference & Value of Significance \\
\hline 1 & 98.50 & .000 \\
3 & 87.08 & .000 \\
4 & 90.40 & .000 \\
5 & 82.70 & .000 \\
\hline
\end{tabular}

Note: Statistical analysis compared to Group 2 (positive control), Group 1: Negative control, Group 3: Test group 1 (18\% infusion), Group 4 : Test group 2 (36\% infusion), Group 5: Test group 3 (72\% infusion) 
showed that there's a significant value $(\mathrm{p}<$ 0.05 ) of treatment group 3 , group 4 , and group 5 compared to group 2 as the positive control group.

The effects of triglyceride reduction were caused by beta glucan, soluble fiber that can reduce lipid absorption in the intestine.5-7 The result of this study was analogous with the study conducted by Jeong et al. ${ }^{4}$ in South Korea, who performed a research about the effect of biopolymer extracted from the different parts of red ear fungi to hyperlipidemic SpragueDawley rats. The study showed that every part of red ear fungi has significant reduction of triglyceride level in hyperlipidemic rats.

The study was performed using red ear fungi obtained from different geographical conditions and using a different type of rats from this study. Also, the red ear fungi were given in the form of extraction, different from the infusion that was used in this study. This study proved that red ear fungi infusion from LIPI Bogor, West Java, had similar triglyceride lowering effect.

An effective dose is a dose that can give optimal pharmacological effect in certain amount. In pharmacological science, the effectiveness of a dose is corresponding with how many component of a drug binding with a specific receptor. ${ }^{12}$ This study used 3 different concentrations of infusion, 18\% (group 3), $36 \%$ (group 4), and $72 \%$ (group 5). A statistical test was performed to compare the treatment group with group 2 as the control positive group. Statistical test showed group 4 had the biggest mean difference of all treatment groups.

iving higher concentrations in this study was not accompanied by increased blood tryglyceride-lowering effects. This condition was likely due to other active substances contained in the fungus, so that the effects were not only tryglyceride-lowering, but could also inhibit tryglyceride reduction effect. So that the effects obtained from this study were the effects of the accumulation of substances contained in the ear fungus infusion.

Based on the study conducted, red ear infusion reduced blood triglyceride level in dyslipidemic rats and red ear infusion with $36 \%$ concentration reduced blood triglyceride optimally in dyslipidemic rats. A further study can be performed to find the concentration range in which the infusion reduces blood triglyceride level optimally.

\section{References}

1. Mitchell RN, Schoen FJ. Blood vessels. In: Kumar V, Abbas A, Fausto N, Aster J, editors. Robbins and cotran pathologic basis of disease. 7th ed. Philadelphia: Saunders; 2010. p. 487-528.

2. Mackay J, Mensah GA. The atlas of heart disease and stroke. World Health Organization (WHO) \& Centers for Disease Control and Prevention (CDC); 2004 [Cited 2012 September15]; Available at: http:// www.who.int/cardiovascular_diseases/ resources/atlas/en/.

3. Rahmat P, editor. Buku pintar bertanam jamur konsumsi. Jakarta: PT AgroMedia Pustaka; 2009.

4. Jeong $\mathrm{H}$, Yang B-K, Jeong Y-T, Kim G-N, Jeong Y-S, Kim S-M, et al. Hypolipidemic effects of biopolymers extracted from culture broth, mycelia, and fruiting bodies of auricularia auricula-judae in dietaryinduced hyperlipidemic rats. Mycobiology. 2007;35(1):16-20

5. Chen WL, Anderson JW. Hypocholesterolemic effects of soluble fiber. In: Vahouny GV, Kritchevsky D, editors. Dietary fiber: basic and clinical aspects. New York: Plenum Press; 1986. p. 275-86.

6. Khoury DE, Cuda C, Luhovyy BL, Anderson GH. Beta glucan: health benefits in obesity and metabolic syndrome. J Nutr Metab. 2012;2012:851362.

7. Ma Z, Wang J, Zhang L, Zhang Y, Ding K. Evaluation of water soluble $\beta$-d-glucan from auricularia auricular-judae as potential anti-tumor agent. Carbohydrate Polymers. 2010;80(3):977-83.

8. Syamsuni HA. Ilmu resep. Jakarta: Penerbit Buku Kedokteran EGC; 2005.

9. Cole T, Kotzsch S, McNamara J. Measurement oftriglycerideconcentration. In: Rifai N, Warnick G, Dominiczak M, editors. Handbook of lipoprotein testing. Washington: AACC Press; 1997. p. 115-26.

10. Dahlan MS. Statistik untuk kedokteran dan kesehatan. 5th ed. Jakarta: Salemba Medika; 2011.

11. Sudjana. Desain dan analisis eksperimen. 4th ed. Bandung: Tarsito; 2002.

12. Henry RB, Zastrow Mv. Drug receptors \& pharmacodynamics. In: Katzung BG, editor. Basic and clinical pharmacology. 10th ed. San Fransisco: Lange, McGraw Hill; 2007. p. 11-33. 